\title{
Analisis Maqashid Syariah tentang Menjaga Harta terhadap Penangguhan Penyerahan Jaminan Logam Mulia Kolektif
}

\author{
Sheillavy Azizah, Sandy Rizki Febriadi, Popon Srisusilawati \\ Program Studi Hukum Ekonomi Syariah, Fakultas Syariah, Universitas Islam Bandung \\ Jl. Tamansari No. 140116 \\ sheillavy77@gmail.com,2prisha587@gmail.com,3po2nss@gmail.com
}

\begin{abstract}
Abstarct-Safeguarding assets is a reflection of economic activity that is obligatory to be obeyed and practiced by everyone in order to meet the necessities of life. One of the gold investment products available at the Syariah branch of Purwakarta branch is precious metal financing, which is a murabaha financing, which is a form of financing on credit or installments. The purpose of this study was to determine the analysis of maqashid sharia about safeguarding assets against the suspension of surrender of collateral precious metals collateral. This study used a qualitative method, a normative juridical approach and the nature of descriptive research. Primary and secondary data types are sourced through interviews and observations of the Islamic Pegadaian. The results showed that according to Imam Syatibi guarding or maintaining property in accordance with the provisions of the shariah maqashid which is forbidden to steal and sanction against it, forbidden cheating and treason in doing business, forbidden usury, forbidden to eat other people's property in a false manner, obliged to replace items that have been damaged by damage. Thus the sharia pawnshop has implemented the maqashid sharia principle in safeguarding assets.
\end{abstract}

Keywords-Maqashid Syariah, Safeguarding Treasure, Precious Metals

Abstrak-Penjagaan harta merupakan cerminan dari kegiatan ekonomi yang wajib hukumnya untuk dipatuhi dan diamalkan oleh setiap orang guna memenuhi kebutuhan hidup. Salah satu produk investasi emas yang tersedia di pegadaian syariah cabang purwakarta adalah pembiayaan logam mulia merupakan pembiayaan murabahah yang salah satu bentuk pembiayaannya secara kredit atau angsuran. Tujuan penelitian ini untuk mengetahui analisis maqashid syariah tentang menjaga harta terhadap penangguhan penyerahan jaminan logam mulia kolektif, Penelitian ini menggunakan metode kualitatif, pendekatan yuridis normatif dan sifat penelitian deskriptif. Jenis data primer dan sekunder yang bersumber melalui wawancara dan observasi Pegadaian Syariah. Hasil penelitian menunjukan bahwa Menurut Imam Syatibi menjaga atau memelihara harta sesuai dengan ketentuan maqashid syariah yaitu dilarangnya mencuri dan sangsi atasnya, dilarang curang dan berkhianat di dalam berbisnis, dilarangnya riba, dilarang memakan harta orang lain dengan cara yang bathil, kewajiban mengganti barang yang telah dirusaknya. Dengan demikian pegadaian syariah telah melaksanakan prinsip maqashid syariah dalam menjaga harta. Mulia

Kata Kunci-Maqashid Syariah, Menjaga Harta, Logam

\section{PENDAHULUAN}

Allah swt sebagai pembuat syari'at tidak menciptakan suatu hukum dan aturan dimuka bumi ini tanpa tujuan dan maksud begitu saja, melainkan hukum dan aturan itu diciptakan dengan tujuan dan maksud tertentu. Syari'at diturunkan oleh Allah pada dasarnya bertujuan untuk mewujudkan kemaslahatan hamba sekaligus untuk menghindari kerusakan, baik di dunia maupun di akhirat. 1 Islam memandang penting persoalan ekonomi, merupakan bagian dari kehidupan manusia yang tidak dapat dipisahkan. Aspek perekonomian merupakan aspek terpenting bagi keberlangsungan hidup umat manusia. Dalam konsep Islam, hal ini tertuang ke dalam lima hal pokok dalam kehidupan manusia yang harus dijaga. Lima hal tersebut disebut kebutuhan primer, yakni menjaga agama, menjaga jiwa, menjaga akal, menjaga keturunan, dan menjaga harta. Penjagaan harta merupakan cerminan dari kegiatan ekonomi yang wajib hukumnya untuk dipatuhi dan diamalkan oleh setiap orang guna memenuhi kebutuhan hidup. 2

Menurut Imam Syatibi menjaga atau memelihara harta sesuai dengan ketentuan maqashid syariah yaitu dilarangnya mencuri dan sangsi atasnya, dilarang curang dan berkhianat di dalam berbisnis, dilarangnya riba, dilarang memakan harta orang lain dengan cara yang bathil, kewajiban mengganti barang yang telah dirusaknya. Masyarakat menengah keatas pada umumnya menyimpan sebagian pendapatannya guna diperuntukan pada masa yang akan datang. Oleh karena itu sebagian masyarakat menginvestasikan dalam bentuk emas logam mulia, emas merupakan investasi yang aman bagi pemula, investasi emas berupa logam mulia (LM) adalah yang paling mudah dengan return yang bagus, serta resiko yang lebih kecil dan bisa sebagai lindung nilai saat krisis.

Sejak masa kolonial Belanda, di Indonesia telah mengenal praktik pegadaian, Tujuan berdirinya pegadaian saat itu adalah untuk menekan praktek pegadaian ilegal serta memperkecil lintah darat yang sangat merugikan masyarakat, serta merupakan lembaga pemberi 
pembiayaan yang sederhana, mudah dan cepat. Lahirnya peraturan pemerintah Nomor 10 Tahun 1990 menegaskan misi yang harus diemban oleh pegadaian untuk mencegah praktik riba, dimana misi ini tidak berubah hingga terbitnya PP. Nomor 103 Tahun 2000 yang dijadikan landasan sampai sekarang.3 Salah satu produk investasi emas yang tersedia di pegadaian syariah cabang purwakarta adalah pembiayaan logam mulia merupakan pembiayaan murabahah yang salah satu bentuk pembiayaannya secara kredit atau angsuran. Secara praktik dalam pembiayaan ini melibatkan tiga pihak, yang pertama pihak nasabah, kedua pihak pegadaian syariah yang diminta untuk membelikan nasabah barang yang dikehendaki dan yang ketiga pihak supplier yang menyediakan barang yaitu PT. Aneka Tambang (ANTAM).

Tujuan dari penelitian ini adalah sebagai berikut :Untuk mengetahui bagaimana teori maqashid syariah tentang memelihara harta, Untuk mengetahui bagaimana praktik penangguhan penyerahan jaminan logam mulia kolektif di Pegadaian Syariah Cabang Purwakarta, Untuk mengetahui bagaimana analisis maqashid syariah tentang menjaga harta terhadap penangguhan penyerahan jaminan logam mulia kolektif di Pegadaian Syariah Cabang Purwakarta.

\section{LANDASAN TEORI}

Maqashid Al-Syariah pada dasarnya adalah untuk mewujudkan kemaslahatan dan menghindari segala macam kerusakan, baik di dunia maupun di akhirat.4 Kemashlahatan yang menjadi tujuan syariat ini dibatasi dalam lima hal yakni: memelihara agama, jiwa, akal, keturunan dan harta. Kelima hal tersebut dibagi menjadi tiga tingkatan kebutuhan yaitu al-dlorruriyat, al-hajiyat dan al-tahsinat.5

Kajian teori maqashid syariah dalam hukum Islam adalah sangat penting. Urgensi itu didasarkan pada pertimbangan-pertimbangan sebagai berikut. Pertama, hukum Islam adalah hukum yang bersumber dari wahyu Tuhan dan diperuntukkan bagi umat manusia. Oleh karena itu ia selalu berhadapan dengan perubahan sosial. Dalam posisi itu apakah hukum Islam sebagai sumber utamanya (Al-Qur'an dan Sunnah) turun pada beberapa abad yang lampau dapat beradaptasi dengan perubahan sosial.jawaban terhadap pertanyaan itu bisa dijawab setelah melakukan kajian terhadap berbagai elemen hukum Islam, dan salah satu elemen yang terpenting adalah teori maqashid syariah. Kedua, dilihat dari aspek historis, sesungguhnya perhatian terhadap teori ini telah dilakukan oleh Rasulullah SAW, para sahabat dan generasi mujtahid sesudahnya, Ketiga, pengetahuan tentang maqashid syariah merupakan keberhasilan mujtahid dalam ijtihadnya, karena diatas landasan tujuan hukum itulah setiap persoalan dalam bermu'amalah antar sesama manusia dapat dikembalikan. 6

Pemahaman kita tentang maqashid al-syari'ah menjadi penting agar kita bisa memberikan penilaian dan mengambil sikap dalam setiap transaksi. Harapannya, kita bisa menjadi pengawal agar setiap transaksi ekonomi dan keuangan bisa mengikuti perkembangan zaman namun sekaligus tidak akan lepas dari prinsip dasar syariat. Maqashid al-syari'ah ini diharapkan akan membantu kita dalam menentukan kebolehan sebuah bentuk akad/transaksi, instrumen keuangan dan bisnis, serta memahami permasalahan mashlahah dan mafsadah.

Indikator maqashid syariah dalam menjaga harta menurut Ahmad Al-Mursi Husain Jauhar dalam buku Maqashid Syariah, yaitu harta dikumpulkan dengan cara yang halal, dipergunakan untuk hal-hal yang halal, dan dari harta ini harus dikeluarkan hak Allah dan masyarakat tempat dia hidup. namun tanpa ada pemborosan, dan diharamkannya riba, dilarang memakan harta orang lain dengan cara yang bathil. 7

Sedangkan menurut Imam Syatibi menguraikan bagaimana menjaga atau memelihara harta sesuai dengan ketentuan maqashid syariah, yaitu : Dilarangnya mencuri dan sangsi atasnya, Dilarang curang dan berkhianat di dalam berbisnis, Dilarangnya riba, Dilarang memakan harta orang lain dengan cara yang bathil, Kewajibkan mengganti barang yang telah dirusaknya. 8

Formula maqashid syariah di dalam memelihara atau menjaga harta adalah tetap memprioritaskan yang primer, yaitu menjaga agama dan dengan menjaga keutuhan yang primer dengan perihal lainnya, termasuk diantaranya menjaga harta. Untuk itu dalam ekonomi islam, harta memiliki fungsi yang terus di manfaatkan oleh manusia, sehingga kecenderungan manusia untuk terus menguasai dan memiliki harta tidak pernah surut. Dalam hal ini , syariat memberi batasan fungsi dan peran harta, yaitu Pertama untuk mendukung kegiatan peribadatan. Kedua untuk memelihara dan meningkatkan keimanan sebagai usaha mendekatkan diri kepada Allah seperti bersedekah dengan harta. Ketiga untuk keberlangsungan hidup dan estafet kehidupan. Keempat untuk menyelaraskan kehidupan di dunia dan di akhirat.9

Harta merupakan salah satu kebutuhan inti, dimana manusia tidak akan terpisah darinya.

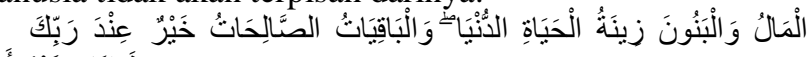

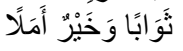


saleh adalah lebih baik pahalanya di sisi Tuhanmu serta lebih baik untuk menjadi harapan. (QS.Al-Kahfi(18) :46)

\section{HASIL DAN PEMBAhasan}

Menurut penulis penangguhan penyerahan jaminan di pegadaian syariah cabang purwakarta telah sesuai dengan ketentuan maqashid syariah dalam menjaga harta. Karena Pegadaian Syariah telah menjalankan prinsip maqashid syariah dalam menjaga harta seperti (1) Dilarangnya mencuri, Menurut Ali as-Shabuni yang dimaksud pencurian adalah mengambil harta orang lain dengan sembunyi-sembunyi tanpa diketahui pemiliknya, jika dikaitkan dengan pegadaian syariah cabang purwakarta ini tidak ada unsur mencuri karena dari pihak pegadaian syariah tidak menggunakan jaminan nasabah baik secara sembunyi-sembunyi ataupun terang-terangan, karena jaminan ini sebagai amanah. (2) Dilarang curang dan berkhianat di dalam berbisnis, Menurut Evan Hamzah Muchtar perbuatan curang dan khianat dalam istilah bahasa arab disebut gharar dan tagrir yaitu adanya tipuan dan tindakan merugikan orang lain dari segi tidak ada kepastian baik objek, kuantitas, kualitas dan penyerahan objek, sedangkan di pegadaian syariah cabang purwakarta penangguhan penyerahan jaminan di pegadaian tidak termasuk unsur curang, berkhianat dalam berbisnis karena pegadaian syariah cabang purwakarta telah memiliki produk yang pasti dan jelas, tidak adanya penangguhan jaminan yang dilakukan pegadaian syariah kepada nasabah, hanya saja pegadaian syariah menunda penyerahan barang karena pihak pegadaian syariah masih proses pemesanan kepada pihak supplier yaitu PT ANTAM karena terbatasnya stok logam mulia dan banyaknya peminat logam mulia menyebabkan nasabah harus menunggu, akan tetapi pemberian jaminan tidak melewati kesepakatan saat akad disepakati. (3) Dilarangnya Riba, Menurut Wasilul Chair dalam jurnalnya ia menyebutkan bahwa riba itu adalah tambahan(azziyadah), berkembang ( an-numuw), membesar (al-uluw) dan meningkat (al-irtifa') yang berarti dalam Pegadaian Syariah Harga jual Emas (tsaman) tidak boleh bertambah selama jangka waktu perjanjian meskipun ada perpanjangan waktu setelah jatuh tempo, Emas yang dibeli dengan pembayaran tidak tunai boleh dijadikan jaminan (rahn), Emas yang dijadikan jaminan tidak boleh dijualbelikan atau dijadikan objek akad lain yang menyebabkan perpindahan kepemilikan. dengan demikian di Pegadaian Syariah tidak ada unsur riba karena telah sesuai dengan fatwa DSN MUI Nomor 77/DSNMUI/VI/2010 tentang jual beli Emas secara tidak tunai. (4) Dilarangnya Memakan Harta orang lain dengan cara yang bathil, jelas bahwa pegadaian tidak mengambil jaminan atau harta nasabah dengan cara yang tidak benar melainkan mereka mendapatkan upah dan keuntungan dari hasil kerja di pegadaian syariah dan komoditas emas itu termasuk komoditas yang sangat berharga maka pihak pegadaian syariah dan nasabah pasti melakukan ijab qabul, ini terbukti bahwa pegadaian syariah telah melakukan prinsip maqashid syariah terhadap menjaga harta dengan tidak memakan harta orang lain dengan cara yang batil. (5) kewajiban mengganti barang yang dirusaknya. Nasabah memiliki hak untuk meminta ganti rugi kepada pihak pegadaian selaku pemegang gadai yang bertanggung jawab atas barang jaminannya. Sedangkan kewajiban bagi nasabah adalah tetap melunasi hutangnya kepada pegadaian syariah, dan pegadaian syariah akan memberikan ganti rugi kepada nasabah atas hilangnya atau rusaknya barang jaminan. Melainkan termasuk yang merugikan nasabah dari sisi waktu dan nilai ekonomis. Nasabah harus menunggu 15 hari dan kemungkinan adanya kebutuhan ekonomi lainnya yang mendesak dipenuhi.

\section{SIMPULAN}

1. Konsep maqashid syariah tentang memelihara harta berdasarkan kepentingannya ada tiga peringkat yang pertama memelihara harta peringkat daruriyyat seperti tata cara tentang kepemilikan harta dan larangan mengambil harta orang lain dengan cara yang tidak sah, yang kedua memelihara harta peringkat hajiyyat seperti syariat tentang jual beli dengan cara salam, apabila cara ini tidak dipakai maka tidak akan terancam eksistensi harta, melainkan akan mempersulit orang yang memerlukan modal, yang ketiga memelihara harta peringkat tahsiniyyat seperti ketentuan tentang menghindari diri dari pengecohan atau penipuan.

2. Penangguhan penyerahan jaminan di pegadaian syariah ditangguhkan apabila terjadi pelunasan dipercepat dari jangka waktu akad yang telah disepakati, maka penyerahan objek jual beli dijaminkan diserahkan oleh pihak pertama kepada pihak kedua minimal pada bulan ketiga sejak akad ditanda tangani para pihak untuk uang muka 10\%, dan minimal pada bulan kedua sejak akad ditandatangani para pihak untuk uang muka $15 \%$. Penangguhan jaminan tersebut tidak termasuk perbuatan curang atau khianat karena terbatasnya stok logam mulia di pegadaian menyebabkan tertundanya penyerahan jaminan.

3. Lima komponen maqashid syariah menjaga harta menurut Imam Syathibi adalah yang meliputi larangan mencuri, larangan curang dan berkhianat, larangan riba, larangan memakan harta orang lain dengan cara yang batil, dan kewajiban mengganti barang yang telah dirusak. Analisis maqashid syariah tentang menjaga harta terhadap penangguhan penyerahan jaminan logam mulia kolektif di Pegadaian Syariah Cabang Purwakarta menurut penulis tidak termasuk curang khianat dan gharar. Melainkan termasuk yang merugikan nasabah dari sisi waktu dan nilai ekonomis, dan 
sesuai dengan ketentuan

\section{DAFTAR PUSTAKA}

[1] Anshari, A. G. (2006). Gadai Syariah di Indoneisa, Konsep Implementasi dan Institusionalisasi. Yogyakarta: Gadjah Mada University Press.

[2] Harahap, Z. A. (2014). Konsep Maqasid Al-Syariah Sebagai Dasar Penetapan dan penerapannya dalam Hukum Islam. Issudin bin abd al-Salam.

[3] Iswandi, A. (2014). Maslahat Memelihara Harta dalam Ekonomi Islam. Filsafat dan Budaya Hukum, Vol. 15.

[4] Jauhar, A. A.-M. (2010). Maqashid Syariah. Jakarta: Amzah.

[5] Mutakin, A. (2017). Teori Maqashid Al Syariah dan Hubungannya dengan Metode Istinbath Hukum. Kanun Jurnal Ilmu Hukum, Vol. 19 No. 3.

[6] Shidiq, G. (2009). Teori Maqashid Al-Syariah dalam Hukum Islam. Sultan Agung, Vol. XLIV No. 118.

[7] Aprianto, N. E. (2017). Konsep harta dalam tinjauan maqashid syariah. Journal of Islamic Ekonomics Lariba Vol 3, issue 2. 